\title{
21 The Wadden Sea coast challenged by sea level rise
}

\author{
Karsten Reise
}

\begin{abstract}
Global warming will ultimately entail a sea level rise of several metres. However, the rate at which it will rise in the future is still uncertain. The question arises whether dikes built to protect against storm surge flooding will also suffice against a long-term sea level rise on the Wadden Coast. Although much higher dikes are technically possible, costs are likely to escalate. Therefore, no-regret adaptations relieving the outer dike line should be considered as supplementary precaution. Seaward of the dikes, sand nourishments from offshore to inshore could stabilise island positions, supplement sediment accretion rates on tidal flats, and replace stone revetments and brushwood groins. In addition to resulting in wave attenuation, these coastal defence measures would integrate with the landscape and support ecological or touristic functions. Landward of the outer dikes, housing should be above level ground by restoring traditional dwelling mounds, building stilt houses and floating homes. Roads should run on dams. Polders could be permanently inundated, either seasonally or tidally to stop soils from further sinking. More water would diversify the landscape as well as the regional economy with aquaculture, floating gardens and greenhouses. Living with more water could also attract more visitors enjoying water sports and nature. Together, this would spread the risk during disastrous flooding and initiate stepwise the sustainable transformation of the Wadden Coast faced with an unprecedented sea level rise.
\end{abstract}

Keywords: dikes, coastal futures, coastal zone management, sea level rise, Wadden Sea

Egberts, Linde \& Schroor, Meindert (eds.), Waddenland Outstanding: The History, Landscape and Cultural Heritage of the Wadden Sea Region. Amsterdam: Amsterdam University Press, 2018 DOI: 10.5117/9789462986602/CH21 
A global sea level rise follows slowly but inevitably from anthropogenic global warming. This rise is the sum of the thermal expansion of oceanic waters, the meltwater of land ice flowing into the ocean, and polar ice sheets sliding into the sea. Higher sea levels will affect coastal flatlands by inundation and soft shores by erosion. The Wadden Sea coast from the northern Netherlands through the German Bight into southern Denmark is composed of vast shallows - the mudflats, where one can wade across at low tide, along exposed dune islands with sandy beaches, tidal gullies and estuaries, and a wide coastal plain secured by earthen seawalls (dikes) against episodic flooding. The Wadden Sea and Waddenland will not simply submerge when the sea rises, nor will coastal people simply evacuate. They will defend their land, raise dikes, create a buffer against shoreline erosion with sand shipped or piped from offshore, continue trapping suspended sediments to gain land, or perhaps adapt to more water with floating townships. This contribution is not to warn about a coming deluge but is meant to discuss how the Wadden Sea coast can cope with higher levels of the sea.

Debating timely adaptive transformations of the Wadden Sea coast may help us to find viable, no-regret and multiple benefit steps that could prolong the integrity and coherence in this coastal region. A sense of transnational and intergenerational solidarity should steer attempts to master the longterm challenge of sea level rise by precautions rather than by flood disasters. In my introduction, I acknowledge the outstanding role of dikes in the history of the Wadden Sea coast. Second, I discuss the prospects of a sea level rise challenging these dikes. Then I suggest timely coastal transformations by employing more sand nourishments from the sea and accommodating more water on land to stop subsidence and to initiate sedimentation. This would essentially mean living with more water rather than less. These considerations are meant to champion sustainability with respect to natural and cultural values and to encourage the continuation of previous discussions (i.e., Ahlhorn \& Meyerdirks 2010; CWSS 2010; De Vriend \& Van Koningsveld 2012; Fischer \& Reise 2011; Helmer et al. 1996; Hofstede \& Stock 2016; Michael Otto Stiftung 2010; Reise 2015, 2017). My suggestions are also an attempt to stop the further stonewalling of Wadden shores.

\section{Dikes}

Hiking on modern dikes offers spectacular panoramic views over the contrasting realms of the Wadden Sea and Waddenland. Dikes are more than a single-minded pursuit for maximising safety. They constitute a 
symbol of human victory over the rambunctious sea. They protect against drowning, secure property, and allow for dealings and lifestyles similar to further inland. Dikes have removed the sea from the coastal land.

When people began settling on fertile salt marshes, they built dwelling mounds to stay dry during storm surges. This did not interfere with ongoing supplies of fresh sediment with each inundation in their surroundings, which was thus growing with the sea. However, untimely inundations threatened livestock and harvests of hay and other crops. Presumably, this is what sparked dike building. Besides preventing the land from being flooded by the sea, dikes also intercepted rainwater runoff, which could inundate embanked land with fresh water. An elaborate system of ditches and canals enabled the draining of wet terrain, and excess rainwater became sluiced through dikes toward the sea when tides were low. However, the dikes and their associated water management had several side effects.

Dikes expelled further sedimentation on the enclosed land, and draining caused shrinking soils. An inverse topography emerged, with embanked land subsiding below the level of the sea. Where bogs were drained to excavate peat, this coastal inversion became aggravated. Not surprisingly, such an unsustainable situation entailed disasters when storm surges breached feeble dikes. Losses of livestock and people were particularly grave where dwelling mounds had lost their relative height. In response, dikes were built ever stronger and higher. They became trusted, and gradually new farmsteads were no longer built on dwelling mounds at all. Farming and fishing were no longer combined where dikes blocked creeks meandering from the sea to the land. Building massive new dikes required external subsidies and investments. Due to ongoing subsidence and sea level rises, it became necessary to pump water from sunken hinterland upwards to the sea to keep this land dry. Finally, water reservoirs were built by embanking tidal flats, where rainwater was stored when strong onshore winds causing high water levels prevented discharge to the sea.

Dike-building triggered a cascade of effects on landscape and coastal societies. With the accelerating sea level rise in the wake of anthropogenic climate change, the subsiding Waddenland is in peril. Although higher dikes are technically possible, the costs of building them will escalate. As an extreme example, at Nordstrand in the northern Wadden Sea, upgrading only 2.5 kilometres of dike entailed costs of 32 million euros (Klimaschutz Deich am Nordstrand 2017). This is almost half of the annual budget for coastal defence in the state of Schleswig-Holstein. Columns of sand penetrating soft ground to prevent subsidence of the massive new dike particularly increased the costs. Such precautions against storm surges raise questions of costeffectiveness and the capacity to meet financial obligations for future dikes. 


\section{Sea level}

Changes in sea level are trivial on steep coasts but highly relevant where the slope from the sea to the land is as flat as on the Wadden Sea coast. Although dikes and dunes interrupt this extreme flatness, the likelihood and magnitude of the future sea level rise may question their long-term ability to secure coastal business as usual.

The level of the sea rose by about three millimetres per year from 1993 to 2014 (Chen et al. 2017). This is twice the average calculated over the last two centuries but may not seem threatening for a coast where tidal ranges and storm surge heights are measured in metres. However, long-term projections of climate scenarios suggest a possible range of 25 to $5^{2}$ metres higher than today in the course of the next few thousand years, caused by greenhouse gas emissions in this century (Clark et al. 2016). We are about to leave the comfortable phase of the late Holocene with a relatively stable climate and sea level, which is what coastal societies were used to. The disintegration of polar ice sheets could raise the sea level in pulses, as happened in the last interglacial period at a similar global temperature as today (O'Leary et al. 2013). Then, the sea level rose by four to six metres within a few centuries. Large chunks of ice slipped into the ocean. This could happen again and would be a fundamentally new situation for populated coasts.

There is widespread agreement on an accelerating sea level rise. Most estimates are for an increase of around one-half to one metre by the end of this century, and more than two metres in the coming centuries in the North Sea region (Wahl et al. 2013; Katsman et al. 2011, Slangen et al. 2014). However, the likelihood cannot be inferred from current ongoing measurements of sea level rise. Sea level rises in the future will depend primarily on ice sheet dynamics in both polar regions (DeConto \& Pollard 2016; Hvidberg 2016; Bakker et al. 2017). The known 'unknowns' of these poorly understood processes may be reduced by further research. However, as with avalanches or earthquakes, the exact timing will remain essentially unpredictable.

This double bind may block long-term strategies for coastal adaptations. On the other hand, many coastal challenges require timely debates. Examples are the lifetimes of coastal defence structures, the effective reach of land use planning, time elapsing from the first planning to final decisions on such controversial coastal issues as dredging estuaries deeper, building storm surge barriers, extending or building new harbours, removing coastal power plants, or giving permissions for drilling gas and oil. All these have implications that reach beyond or this century. Assumed rates of sea level rise or possible sea levels in the next century will likely have effects on such 
coastal measures and on public opinion. Uncertainties call for no-regret measures and the rejection of irreversible ones.

\section{Sand}

Facing an accelerating sea level rise, the entire Wadden Sea coast may run into a negative sediment budget. Therefore, transferring sand from offshore to inshore sites could supplement natural sedimentation in an attempt to keep up with the sea level rise. The North Sea bottom has plenty of sand, mostly originating from a Palaeogene river delta and Neogene glacial depositions. This offshore resource of sand should not only be used for compensating actual inshore losses. With a precautionary strategy, the costs for hard coastal defences and introducing alien materials into the coastal environment could be avoided. Precautionary sand nourishments constitute a long-term and no-regret adaptation by growing along with the level of the sea.

At exposed Wadden Sea island beaches, repeated sand nourishment to hold the line has already become standard practice (CWSS 2010; WWF 2015). Besides holding the line, such sand supplies have the benefit of maintaining the quality of recreational beaches and could support dune-building (Bakker et al. 2012). Moreover, sand washed away may supplement downstream sediment budgets, i.e., in adjacent tidal basins. To maintain tidal flats there, offshore sand could also be dumped into tidal channels for natural redistribution. Saving the area and level of tidal flats by such means would benefit coastal defence by absorbing wave energy and would support nature protection by preventing the loss of feeding grounds for spectacular flocks of coastal birds (Hofstede \& Stock 2016).

Offshore sand could be used to cover armoured shores or cushion dikes with ridges of dunes. This could spare other enforcements. It offers a more natural transition between the land and the sea for the sake of both nature protection and recreation. Furthermore, rectangular fields of brushwood groins facilitating sediment accretion could be replaced by sand bars or sandy hooks supplied by sand nourishment. On their lee sides, mud deposition could take place and salt marsh succession could begin. Nourished dunes, beaches, sand bars and sandy hooks may last for several decades at sheltered inshore positions and would be a better fit with the Wadden Sea World Heritage status than the prevailing artificial hard structures. Sand washed away from sites of nourishment within decades would remain in the Wadden Sea for centuries, supplementing the inshore sediment budget for growing with the level of the sea. 


\section{Water}

In the Waddenland, old dikes or their remnants bear testament to the history of claiming or reclaiming land. Polders with their dates of embankment and their depth relative to the sea level further reveal the history of water control for improving the use of land. However, the divergence between sunken land level and the rising sea is aggravating. Could this unsustainable development be mitigated with a comeback of more water?

Higher water levels could stop soils from shrinking. Instead of emitting carbon dioxide, wet polders with marsh plants could serve as carbon sinks for the atmospheric excess of $\mathrm{CO}_{2}$. At the same time, such polders would become rich in wildlife and could attract tourism. Wet polders could also be used for harvesting reeds and as pasture for water buffaloes or wild horses. In the outer dike, sluices could be rebuilt for letting tidal waters flowing back and forth. The created tide polders could accrete sediment from flood waters (such as with Luneplate Island on the River Weser near Bremerhaven). Particularly under estuarine conditions, one can expect high rates of sedimentation that could raise the level of the embanked land back to the level of the sea (Reise 2015). Tide polders could be used for aquaculture, as recreational areas, and to restore coastal biodiversity. However, such a reversal of the traditional land use practice is bound to meet resistance, and no concerted projects have yet been undertaken.

A main reason for this dilemma may be that more water in the landscape entails not only new ways of land use but also infrastructural adaptations. Roads need lifting onto dams. Together with existing old dikes, this could compartmentalise the landscape. Individual polders could then be managed in their own way with regard to water: dry arable land, seasonal or tidal flooding or even permanent inundation. Traditional dwelling mounds would be pre-adapted toward returning water. Houses on level ground could be lifted onto new mounds or set on stilts or floats.

Such far-reaching transformations would be only possible in viable steps. The partial loss of arable land and pasture could be compensated by an improved landscape diversity attracting tourism and residential areas. Floating homes would be accessible by boardwalks or water taxi. Floating gardens or greenhouses could be combined with various forms of aquaculture. Central rescue towers on mounds for emergency in case storm surges breach dikes could serve manifold functions when not needed for rescue: panorama restaurant, fire department, health station, etc.

Creating floating infrastructures or raising them to a higher level spreads the risks that hitherto were mitigated entirely by outer dikes. Living in the 
low marshes would be less vulnerable. Traditional farm houses, churches or even entire villages on dwelling mounds would be accentuated in the transformed landscape. Canals could regain their former importance. The rewetted coastal landscape would become more distinct again from landscapes further inland. This also applies to the concomitant lifestyle adjusted to more water. The mosaic structure with polders of various water levels would mean a diversified economy replacing the current hegemony of agriculture.

\section{Outlook}

The sea level rise should be kept within limits by proper climate policies. However, even though the 2015 Paris Agreement intends to keep 'well below' $2^{\circ}$ Celsius of global warming, inherent inertia will cause the sea level to rise for many centuries to come. As communities that will be directly affected by this, societies in coastal flatlands adjacent to a rough North Sea should pioneer the reduction of greenhouse gas emissions. Power plants fired with coal imported from overseas and for which estuarine waterways have to be dredged ever deeper (i.e., at Eemshaven, Wilhelmshaven, Hamburg, Esbjerg) are intolerable on a coast rich in wind energy and subject to concomitant sea level rise.

Although a sea level rise is certain to occur, the rate of sea level rise is still being debated and is often believed to be occurring slowly enough to be able to postpone adequate adaptations. However, merely reinforcing dikes will be at the expense of the generations to come if this is not combined with a general concept of growing with the level of the sea via sand nourishments and by accommodating more water on land. Given the length of time we are talking about here, we can expect many environmental and societal conditions to change just as much as the sea level. Will the coastal environment remain healthy and economically viable? Will airborne traffic make roads and waterways superfluous? Will natural and cultural assets still be valued? Will present states and languages of the Wadden Sea coast persist? Spiritual domains may change entirely. In contrast to such imponderables and vagaries, we can be reasonably sure that the sea level will be much higher than today and that dikes alone will not suffice. Acting accordingly now and enjoying the benefits of timely coastal transformations would be more fulfilling and meaningful than postponement. 


\section{References}

Ahlhorn, F. and Meyerdirks, J. (2010). Speichern statt pumpen. Wilhelmshaven: Nationalpark- und Biosphärenreservatsverwaltung Niedersächsisches Wattenmeer.

Bakker, M., Van Heteren, S., Vonhögen, L., Van der Spek, A., \& Van der Valk, B. (2012). Recent coastal dune development: Effects of sand nourishments. Journal of Coastal Research, 28(3), 587-601.

Bakker, A.M.R., Wong, E.T., Ruckert, K.L. and Keller, K. (2017). Sea-level projections representing the deeply uncertain contribution of the West Antarctic ice sheet. Scientific Reports 7: 3880.

Chen, X., Zhang, X., Monselesan, D., Legresy, B., Church, J.A., Watson, C.S., King M.A. and Harig, C. (2017). The increasing rate of global mean sea-level rise during 1993-2014. Nature Climate Change 7, 492-495.

Clark, P., Shakun, J., Marcott, S., Mix, A., Eby, M., Kulp, S., Levermann,A., Milne, G.A., Pfister, P.L., Santer, B. D., Schrag, DP., Solomon, S., Stocker, T.F., Strauss, B.H., Weaver, A.J., Winkelmann, R., Archer, D., Bard, E., Goldner, A., Lambeck, L., Pierrehumbert, R.T. and Plattner, G. (2016). Consequences of twenty-firstcentury policy for multi-millennial climate and sea-level change. Nature Climate Change 6, 360-369.

CWSS (Common Wadden Sea Secretariat) (2010). Coastal protection and sea level rise. Wadden Sea Ecosystem 28. Wilhelmshaven: CWSS. www.waddensea-secretariat. org/sites/default/files/downloads/cps_third_report.pdf.

DeConto, R.M. and Pollard, D. (2016). Contribution of Antarctica to past and future sea-level rise. Nature 531, 591-597.

De Vriend, H.J. and Van Koningsveld, M. (2012). Building with nature: Thinking, acting and interacting differently. Dordrecht: EcoShape.

Fischer, L., Reise and K. (eds.) (2011). Küstenmentalität und Klimawandel. Küstenwandel als kulturelle und soziale Herausforderung. Munich: Oekom.

Helmer, W., Vellinga,P., Litjens, G., Goosen, H., Ruijgrok, E. and Willem Overmans (1996). Growing with the sea: creating a resilient coastline. Zeist: World Wide Fund for Nature (WWF).

Hofstede, J.L.A. and Stock, M. (2016). Climate change adaptation in the SchleswigHolstein sector of the Wadden Sea: An integrated state governmental strategy. Journal of Coastal Conservation. doi: org/10.1007/s11852-016-0433-0.

Hvidberg, C.S. (2016). Ice sheet in peril. Science 351, 562-563.

Katsman, C., Sterl, A., Beersma, J., Van den Brink, H., Church, J., Hazeleger, W., Kopp, R.E., Kroon, D., Kwadijk, J., Lammersen, R., Lowe, J., Oppenheimer, M., Plag, H.-P., Ridley, J., Storch, H. von, Vaughan, D.G., Vellinga, Vermeersen, L. L. A., R S; Wal, R. S. W. van de and Weisse, R. (2011). Exploring high-end scenarios 
for local sea level rise to develop flood protection strategies for a low-lying delta - the Netherlands as an example. Climatic Change 109, 617-645.

Klimaschutz Deich am Nordstrand: 'Alle wussten dass da Steine drin sind (2017, 23 June),' Husumer Nachrichten. Retrieved from https://www.shz.de/lokales/ husumer-nachrichten/klimaschutz-deich-auf-nordstrand-alle-wussten-dassda-steine-drin-sind-id17124761.html.

Michael Otto Stiftung (ed.) (2010). Ein Zukunftsbild für eine klimasichere Wattenmeerregion. www.michaelottostiftung.de

O’Leary, M.J. Hearty, P., Thompson, W., Raymo, M., Mitrovica, J., \& Webster, J. (2013). Ice sheet collapse following a prolonged period of stable sea level during the last interglacial. Nature Geosciences 6, 796-8oo.

Reise, K. (ed.) (2015). Kurswechsel Küste: Was tun, wenn die Nordsee steigt? Kiel: Wachholtz.

Reise, K. (2017). Facing the third dimension in coastal flatlands. GAIA 26(2), 89-93. Slangen, A., Carson, M., Katsman, C., Van de Wal, R., Köhl, A., Vermeersen, L., and Stammer, D. (2014). Projecting twenty-first century regional sea-level changes. Climatic Change 124, 317-332.

Wahl, T., Haigh, I., Woodworth, P., Albrecht, F., Dillingh, D., Jensen, J., Nicholls, R.J., Weisse, R. and Wöppelmann, G. (2013). Observed mean sea level changes around the North Sea coastline from 1800 to present. Earth-Science Reviews 124, 51-67. WWF Deutschland (2015). Klimaanpassung an weichen Küsten. Fallbeispiele aus Europa und den USA für das schleswig-holsteinische Wattenmeer. Husum: WWF Deutschland.

\section{About the author}

Prof. Karsten Reise is a retired coastal ecologist from the Alfred Wegener Institute. He lives on the island of Sylt, with mud at his feet, sand in his heart and a deep desire for water. He has been professor of marine zoology, biological oceanography and coastal ecology at the universities of Göttingen, Hamburg and Kiel, respectively. His written or edited works include Tidal Flat Ecology (Springer 1985), Ökosystem Wattenmeer (Springer 1998), Ecological Comparisons of Sedimentary Shores (Springer 2000), Küstenmentalität und Klimawandel (oekom 2011), A natural history of the Wadden Sea / Eine Naturgeschichte vom Wattenmeer (Waddenacademie Leeuwarden 2013/2014), and Kurswechsel Küste: Was tun, wenn die Nordsee steigt? (Wacholtz/Murmann 2015). 
A Amsterdam

U University

P Press 